Conclusion A paediatric simulation programme run in-situ on a paediatric ward increases medical student's confidence in recognising and managing paediatric emergencies, and helps prepare them for working as a foundation doctor. It can also help to develop paediatric trainee's skills in leadership, education and facilitation.

\section{G120(P) 2 YEAR NEURODEVELOPMENTAL FOLLOW UP, A QUALITY IMPROVEMENT PROJECT: MEETING METRICS VS DELIVERING QUALITY ASSESSMENTS}

${ }^{1} \mathrm{M}$ Parmar, ${ }^{1} \mathrm{~N}$ Merchant, ${ }^{2} \mathrm{~S}$ Beasley, ${ }^{1} \mathrm{P}$ Southernwood, ${ }^{1} \mathrm{~B}$ Sivakumar, ${ }^{1} \mathrm{~S}$ Narayanan. ${ }^{1}$ Department of Paediatrics and Neonatology, West Hertfordshire NHS Trust, Watford, UK; ${ }^{2}$ Physiotherapy Department, Peace Children's Centre, Watford, UK

\subsection{6/archdischild-2018-rcpch.116}

Introduction Neurodevelopmental outcome assessment is a critical aspect of care for high-risk infants and provides basis for benchmarking, early intervention, and endpoints for research studies. Validated tools are recommended to assess neurodevelopment. National Neonatal Audit Programme data (2013) showed 2 year impairment free survival for $<30$ weeks was $44 \%$ but data was available for only $44 \%$.

Aim To improve 2 year neurodevelopmental assessments and correlate developmental scores with risk factors.

Methods Local data(2013) showed 69\% compliance to 2 year appointments with zero formal assessments. Using Quality Improvement Tools we planned to improve formal developmental assessements by $50 \%$ and 2 year attendances. Appointments were given on discharge, reminders and alerts set up for 18-30 months range. Real time data monitoring with zero latency feedback was used to drive improvement. Bayley Scales of Infant and Toddler Development III (BSID) was used for the assessment. Moderate delay was defined as composite score -2 to $-3 \mathrm{SD}$ and severe delay $<-3$ SD in any of the domains. Parental feedback was obtained through an anonymous questionnaire using Likert Scale. Questionaire asked about pre-clinic communication, staff attitude, parent understanding and communication of BSID outcomes. Data analysed using Microsoft Excel.

Results Average age at assessments was 24.9 months. Table 1 shows steady improvement in 2 year assessments. DNA rates increased initially in 2015 on introduction of BSID assessments but using iterative PDSA cycles this was brought down to $3 \%$ in 2017. Mean(SD) composite scores for cognitive domain was 91.9 (14), motor 86.6 (13.7) and language 86.4 (24.8). $14.8 \%$ of children had moderate delay and $8.5 \%$ had severe delay. There appears to be a significant correlation with birth weight $(p=0.03)$ and oxygen days $(p=0.01)$ with cognitive domain.

$\begin{aligned} & \text { Abstract } \\
& 2017\end{aligned}$
\begin{tabular}{lllllll} 
Year (July- & Eligible \\
June) & babies & $\begin{array}{l}\text { 2 year form } \\
\text { completed(\%) }\end{array}$ & $\begin{array}{l}\text { BSID } \\
(\%)^{*}\end{array}$ & $\begin{array}{l}\text { DNA } \\
(\%)\end{array}$ & $\begin{array}{l}\text { Died } \\
\text { 2-year }\end{array}$ & $\begin{array}{l}\text { Moved out } \\
\text { of area }\end{array}$ \\
\hline 2013 & 16 & 69 & 0 & 31 & 0 & 0 \\
2014 & 25 & 80 & 0 & 23 & 0 & 3 \\
2015 & 29 & 100 & 35 & 65 & 0 & 3 \\
2016 & 19 & 89 & 73 & 27 & 1 & 7 \\
2017 & 32 & 100 & 97 & 3 & 0 & 1 \\
\hline
\end{tabular}
*Excluding moved out area/died

Parental feedback was excellent rating the service as 'very good' (5.5/6 on Likert scale).

Conclusion Dedicated administrative services, timely reminders and active management of DNA's improved the attendance and clinic assessments. Identifying key issues, streamlining service efficiency, potentiated an increase in the neurodevelopmental assessments with excellent parental feedback. Correlation with outcomes will allow for improved support in early infancy and facilitate anticipatory guidance and targeted interventions.

\section{G121(P) THE NEW (2016) JUNIOR DOCTORS CONTRACT: EXPERIENCES OF YORKSHIRE-BASED PAEDIATRICS TRAINEES}

${ }^{1} F$ Payne, 1,2M Redman. 'Department of General Paediatrics, Sheffield Children's Hospital, Sheffield, UK; ${ }^{2}$ Department of Oncology and Metabolism, University of Sheffield, Sheffield, UK

\subsection{6/archdischild-2018-rcpch.117}

Aims This project aims to explore the experiences of Yorkshire-based paediatrics trainees of all grades following the recent transition of some trainees to the new (2016) terms and conditions of service (TCS) ${ }^{1}$ for junior doctors in England. The authors intend to identify areas which can be addressed to improve the experience of paediatrics trainees in Yorkshire.

Methods An electronic survey was designed and circulated to paediatric trainees of all grades in the Yorkshire School of Paediatrics between 17th-31 st July 2017.

Results Ninety (25\%) out of 361 trainees responded (including those on maternity leave, excluding those out of programme). Sixty-six respondents (73\%) were full time trainees. The respondents were equally split between those on the 2016 TCS and those on the old (2002) TCS. Thirteen (30\%) of those on the new TCS had exception reported, with five of the 13 trainees (38\%) having experienced exception reports being actioned within two weeks, and two respondents $(5 \%)$ having experienced a work schedule review. Nineteen (44\%) of respondents were either dissatisfied or very dissatisfied with the new contractual limits on working hours.

The main positive experiences identified were: rest rostering, pay, exception reporting, awareness of rest entitlements.

The main negative experiences identified were: swapping shifts more difficult due to safe working hours limits, rota gaps, pay disparity, lower morale.

Conclusion Work is ongoing to begin to address some of these issues in Yorkshire. The results highlighted both contractual and extra-contractual issues. More work is needed to address concerns identified by paediatrics trainees, particularly around morale and rota gaps. Trainees should be encouraged to exception report and exception reports should be actioned within the appropriate timeline. Further work can be pursued to explore if these results are comparable across England, and across other specialty training programmes.

\section{REFERENCE}

1. Junior Doctors Terms and Conditions of Service. NHS Employers. http://www. nhsemployers.org/case-studies-and-resources/2016/05/junior-doctors-terms-andconditions-of-service [Accessed: 14/10/17]. 